INNOVATIONS IN PRIMARY CARE

\title{
Behind the Mask: Identity Formation and Team Building
}

\author{
Mark B. Stephens, MD \\ Penn State University College of Medicine, State College, \\ Pennsylvania
}

Ann Fam Med 2019;17:561. https://doi.org/10.1370/afm.2447.

\section{THE INNOVATION}

Medical schools have the responsibility to create an environment where students and faculty work together to advance the knowledge and skills necessary for the practice of medicine, while simultaneously promoting the development of a sound professional identity. ${ }^{1,2}$ We have successfully implemented the ancient art of mask making to explore identity and use it as an interdisciplinary construct for teambuilding for faculty and students.

\section{WHO \& WHERE}

At the Penn State University College of Medicine, we use mask making as an activity for faculty and students to explore and express their sense of identity as health care professionals. Students and faculty are challenged to think about their roles in health care, specifically as these relate to their overall sense of self as part of a larger team.

\section{HOW}

Each team member is given a blank mask and challenged to think about the personal strengths they bring to the team. They are given 5 to 7 minutes to express a representation of these strengths on one section of the mask. Team members then switch masks with each other and given 5 to 7 minutes to express themselves (either using the same design, or choosing a new design) on the next mask (Supplemental Figure 1, available at http://www.AnnFamMed.org/content/17/6/561/suppl/ DC1). This sequence rotates until the mask has been filled. While painting, organic conversations spring up that allow team members to better get to know each other as they create a shared work of art. At the conclusion of the session, participants are given the opportunity to further explore both product (the mask) and process (mask making). The methodology has been successful with student-faculty teams. We are plan-

Conflicts of interest: author reports none.

\section{Corresponding author}

Mark B. Stephens, MD

Penn State University College of Medicine

1850 East Park Avenue, Suite 304

State College, PA 16803

mstephens3@pennstatehealth.psu.edu ning to implement with care teams (clinicians, administrators, support staff, and allied professionals) later this year.

\section{LEARNING}

Burnout is a significant problem in modern medicine. Students, faculty, and staff are all at risk. Our work with mask making suggests that identity formation plays a significant role in addressing (and potentially mitigating) burnout. Identity formation is an iterative, contextual, and continual process. Elements of "expressed self" depend on who we are with, what we are doing, and how we might be perceived. Language, ritual, and symbol shape the environment within which professional identity shapes and grows. Hierarchies and hidden curricula can lead to identity dissonance. Individuals may "abandon" elements of self as sacrifice to their professional responsibilities. Integrating elements of personal and professional identity in a holistic and healthy way may lead to an increased sense of joy, teamwork, and professional satisfaction in the workplace. Responses to the exercise included:

"I felt that the mask making process was helpful in providing space and time for genuine conversation with folks with whom I do not get to spend much time."

"I felt that the conversation that occurred during the painting was as valuable as the painting process itself."

"I felt very connected to the group since my mask was in a sense also their mask."

"I thought it was a good way to encourage dialogue and conversation, and it was interesting to see how all of our designs coalesced."

"Group mask making opened possibility of informal conversation about professional development."

Submitted March 8, 2019; submitted, revised, April 9, 2019; accepted March 26, 2019.

Key words: physician burnout; teamwork; professional development

Supplemental materials: Available at http://www.AnnFamMed. org/content/17/6/561/suppl/DC1/.

\section{References}

1. Cruess RL, Cruess SR, Boudreau JD, Snell L, Steinert Y. Reframing medical education to support professional identity formation. Acad Med. 2014;89(11):1446-1451.

2. Wald HS, Anthony D, Hutchinson TA, Liben S, Smilovitch M, Donato AA. Professional identity formation in medical education for humanistic, resilient physicians: pedagogic strategies for bridging theory to practice. Acad Med. 2015;90(6):753-760.

3. Joseph K, Bader K, Wilson S, Walker M, Stephens M, Varpio L. Unmasking identity dissonance: exploring medical students' professional identity formation through mask making. Perspect Med Educ 2017;6(2):99-10. 